\title{
The Effect of Production Level on Feed Intake, Milk Yield, and Endocrine Responses to Two Fatty Acid Supplements in Lactating Cows*
}

\author{
K. J. Harvatinet and M. S. Allen \\ Department of Animal Science, Michigan State University, East Lansing 48824
}

\begin{abstract}
Animal responses to dietary treatment may interact with metabolic state, which differs for cows across a wide range of milk yield. Responses to dietary saturated vs. unsaturated fatty acid (FA) supplement was evaluated using 32 multiparous Holstein cows arranged in a crossover design with 14 -d periods. Treatments were 2.5\% FA from unsaturated FA (calcium salts of palm FA) or saturated FA (prilled, hydrogenated free FA). Unsaturated FA treatments decreased dry matter intake $(0.8 \mathrm{~kg} / \mathrm{d})$ and time spent ruminating $(25 \mathrm{~min} / \mathrm{d})$ compared with saturated FA treatment. Treatments did not differ in milk or 3.5\% fat-corrected milk yield. Intake and milk yield responses were not related to milk yield across cows. Saturated FA treatment increased milk protein and lactose concentrations, but treatment did not affect yield of milk components. Saturated FA treatment increased insulin over $25 \%$ and decreased nonesterified FA nearly $20 \%$ with no effect on plasma somatotropin, glucose, or $\beta$-hydroxybutyrate concentrations. Milk protein concentration and yield responses to treatment were positively correlated with pretrial fat-corrected milk yield. Milk protein response was not related to insulin response, supporting the importance of insulin sensitivity in control of milk protein synthesis. Unsaturated FA treatment decreased dry matter intake and rumination time compared with saturated FA treatment, consistent with reports of unsaturated fat increasing satiety and decreasing gut motility. Decreased milk protein synthesis by fat supplementation may be related to FA saturation and milk yield of cows.
\end{abstract}

(Key words: fatty acid, saturation, milk protein, feed intake)

Abbreviation key: $\mathbf{C C K}=$ cholecystokinin, $\mathbf{F A}=$ fatty acid, GLP-1 = glucagon-like peptide-1, $\mathbf{p F C M Y ~ = ~ p r e - ~}$

Received January 13, 2005.

Accepted June 8, 2005.

Corresponding author: Michael S. Allen; e-mail: allenm@msu.edu.

*Research supported in part by Milk Specialties Company, Dundee, IL.

$\dagger$ Present address: Cornell University, Dept. of Animal Science, 223 Morrison Hall, Ithaca, NY 14850. trial fat-corrected milk yield, SAT = saturated fatty acids, $\mathbf{S T}$ = somatotropin, UNS = unsaturated fatty acids.

\section{INTRODUCTION}

Energy required for milk yield and maintenance is often greater than the cow's ability to consume dietary energy, resulting in a negative energy balance. Addition of fat to the diet increases energy density without increasing rumen acid production, thus stabilizing rumen $\mathrm{pH}$ relative to addition of grain. Prilled hydrogenated free fatty acids (FA) and calcium salts of FA are 2 commercially available fat sources that have been designed to reduce adverse effects of FA on rumen microbial fermentation.

The ability of the cow to increase daily energy intake depends on the net energy density of the diet and daily DMI. Intake is highly regulated by animal nutrient requirements and metabolic states, and by the type and temporal absorption of fuels. Allen (2000) observed in a meta-analysis that fat supplements differing in FA source, form, and type have different hypophagic effects. Within commonly fed FA supplements, calcium salts of palm FA linearly decreased DMI with increasing dietary concentration whereas hydrogenated FA had no effect on DMI (Allen, 2000). The concept that absorbed FA of varying saturation have different hypophagic effects was demonstrated through a series of abomasal infusion studies, which showed that decreasing FA saturation decreased DMI (Drackley et al., 1992; Christensen et al., 1994; Bremmer et al., 1998).

Dietary fat has demonstrable effects on milk protein production (DePeters and Cant, 1992). Decreased milk protein concentration and yield with increased dietary fat might be caused by changes in ruminal fermentation, endocrine signaling, milk yield, or mammary nutrient metabolism (DePeters and Cant, 1992). Drackley et al. (1992) observed a linear decrease in milk CP yield with abomasal unsaturated FA infusion, and Christensen et al. (1994) observed decreased milk true protein and casein yield with $\mathrm{C} 18$ unsaturated FA infusion compared with saturated FA, indicating that FA profile has an important role in fat-stimulated decreased milk protein synthesis. 
Dietary energy density is often increased by addition of fat in an attempt to improve the energy balance of high-producing cows that are unable to consume the required amount of forage and grain to meet energy requirements. It is expected that cow response to energy supplementation will depend on the cow's metabolic state or milk yield. Crossover design experiments with a pretrial covariant period allow observation of cow responses across production levels. In the current experiment, responses to FA supplementation were expected to differ for cows varying in milk yield.

The objective of this experiment was to determine the relationship between production level and responses for DMI, milk yield, and plasma hormones and metabolites to diets supplemented with saturated or unsaturated FA supplements. We hypothesized that more highly unsaturated FA would decrease intake relative to saturated FA at equal FA concentrations, and individual cow response would depend on milk yield.

\section{MATERIALS AND METHODS}

\section{Cows and Treatments}

Thirty-two multiparous Holstein cows in mid to late lactation at the Michigan State University Dairy Cattle Teaching and Research Center were randomly assigned to sequence in a crossover design with a pretrial covariant period. During the pretrial period, milk production averaged $43.7 \pm 6.3 \mathrm{~kg}$ with a range from 34.0 to 57.5 $\mathrm{kg}$. Cows averaged $130 \mathrm{DIM}(\mathrm{SD}=70), 2.35 \mathrm{BCS}(\mathrm{SD}=$ $0.38)$, and $655 \mathrm{~kg} \mathrm{BW}(\mathrm{SD}=45)$. Experimental procedures were approved by the All University Committee on Animal Use and Care at Michigan State University. Treatments were $2.5 \%$ added dietary FA from saturated FA (SAT) or unsaturated FA (UNS) sources (SAT = prilled hydrogenated free FA (Energy Booster 100); Milk Specialties Company Inc., Dundee, IL; UNS = calcium salts of palm FA (Megalac); Church and Dwight Company, Inc., Princeton, NJ). Treatments were fed as a mix using ground corn as a carrier, and were balanced for calcium and FA concentration using limestone and rice hulls (Table 1). Covariant and treatment periods were $14 \mathrm{~d}$ in length with the first $10 \mathrm{~d}$ for diet adaptation followed by $4 \mathrm{~d}$ of sample collection. Diets contained alfalfa silage $(\sim 50 \%$ of forage DM), corn silage $(\sim 50 \%$ of forage DM), dry ground corn, whole linted cottonseed (12.5\% of ration DM), protein mix (soybean meal, corn gluten meal, and blood meal), and mineral and vitamin premix (Table 2 ). The base diet contained $\sim 5.0 \% \mathrm{FA}$ with $2.0 \%$ FA from cottonseed. Cows were fed a diet intermediate to both treatments during the pretrial period. Cows were housed in tie stalls throughout the experiment, except for a 1.5 -h exercise period twice
Table 1. Ingredients and nutrient composition of treatments. ${ }^{1}$

\begin{tabular}{|c|c|c|}
\hline & SAT & UNS \\
\hline Ingredient & $\longrightarrow$ & $\%$ of $\mathrm{DM}$ \\
\hline Ca soaps fatty acid (FA) & - & 57.7 \\
\hline Prilled FA & 48.9 & - \\
\hline Rice hulls & - & 10.9 \\
\hline Limestone & 19.2 & - \\
\hline Ground corn & 31.9 & 31.4 \\
\hline \multicolumn{3}{|l|}{ Composition } \\
\hline Total FA & 49.7 & 46.9 \\
\hline Calcium & 6.8 & 7.1 \\
\hline Fatty acid profile & \multicolumn{2}{|c|}{$\%$ of $\mathrm{FA}^{2}$} \\
\hline $\mathrm{C} 16$ & 34.0 & 46.9 \\
\hline C18:0 & 46.2 & 4.3 \\
\hline C18:1 & 9.9 & 36.3 \\
\hline C18:2 & 2.54 & 9.31 \\
\hline C18:3 & 0.04 & 0.30 \\
\hline Unsaturated FA & 13.2 & 46.1 \\
\hline $\mathrm{C} 16: 18$ ratio & 0.58 & 0.94 \\
\hline
\end{tabular}

${ }^{1} \mathrm{SAT}=$ Saturated fatty acid treatment of prilled fatty acids; UNS = unsaturated fatty acid treatment of calcium salts of palm fatty acids.

${ }^{2}$ Fatty acid composition of the treatment mix described above.

Table 2. Ingredient and nutrient composition of experimental diets. ${ }^{1}$

\begin{tabular}{|c|c|c|c|}
\hline & Pretrial & SAT & UNS \\
\hline \multicolumn{4}{|l|}{ Ingredient } \\
\hline Corn silage $^{2}$ & 22.5 & 22.4 & 22.5 \\
\hline Alfalfa silage $^{3}$ & 18.9 & 20.0 & 20.1 \\
\hline Ground corn & 23.8 & 23.1 & 23.1 \\
\hline Whole cottonseed & 10.4 & 10.3 & 10.3 \\
\hline Protein $\operatorname{mix}^{4}$ & 14.1 & 13.8 & 13.9 \\
\hline SAT $\operatorname{mix}^{5}$ & 2.5 & 5.0 & - \\
\hline UNS $\operatorname{mix}^{5}$ & 2.4 & - & 4.6 \\
\hline Mineral-vitamin $\operatorname{mix}^{6}$ & 4.4 & 4.5 & 4.5 \\
\hline Molasses $\mathrm{mix}^{7}$ & 1.0 & 0.9 & 0.9 \\
\hline \multicolumn{4}{|l|}{ Nutrient } \\
\hline $\mathrm{DM}$ & 52.6 & 52.2 & 52.1 \\
\hline Total FA & 7.1 & 7.0 & 6.8 \\
\hline Unsaturated FA, \% & 3.8 & 3.3 & 4.0 \\
\hline Starch & 26.6 & 25.5 & 25.7 \\
\hline NDF & 26.0 & 26.4 & 26.9 \\
\hline Forage NDF & 16.1 & 17.0 & 17.1 \\
\hline $\mathrm{CP}$ & 18.6 & 17.3 & 17.4 \\
\hline Ash & 5.3 & 5.4 & 5.1 \\
\hline Rumen-undegraded $\mathrm{CP}, 8 \% \mathrm{CP}$ & 35.7 & 35.6 & 35.6 \\
\hline
\end{tabular}

${ }^{1}$ Pretrial $=$ covariant period; $\mathrm{SAT}=$ saturated fatty acid treatment of prilled fatty acids; UNS = unsaturated fatty acid treatment of calcium salts of palm fatty acids.

${ }^{2}$ Corn silage contained $37.2 \% \mathrm{DM}$ (as fed) and $39.6 \% \mathrm{NDF}, 7.4 \%$ $\mathrm{CP}, 27.9 \%$ starch, and $3.0 \%$ ash on a DM basis.

${ }^{3}$ Alfalfa silage contained $30.9 \% \mathrm{DM}$ (as fed) and $40.5 \% \mathrm{NDF}, 17.0 \%$ $\mathrm{CP}, 4.2 \%$ starch, and $7.2 \%$ ash on a DM basis.

${ }^{4}$ Protein mix contained $74.1 \%$ soybean meal ( $44 \% \mathrm{CP}$ ), $20.1 \%$ corn gluten meal, and $5.8 \%$ blood meal.

${ }^{5}$ Mix composition as listed in Table 1.

${ }^{6}$ Mineral vitamin mix contained $16.5 \%$ vitamin E, $41.0 \%$ vitamin $\mathrm{D}, 44.4 \%$ vitamin $\mathrm{A}, 1.9 \%$ trace mineral premix, $4.1 \%$ urea, $4.6 \%$ salt, $8.4 \%$ limestone, $10.5 \%$ dicalcium phosphate, $11.7 \%$ sodium bicarbonate, and $57.9 \%$ dry ground corn as a carrier.

${ }^{7}$ QLF Dairy TMR 20 (66\% DM and 30.3\% CP); Quality Liquid Feeds, Dodgeville, WI.

${ }^{8}$ Rumen-degraded protein estimated using values from NRC (2001). 
daily before milking in a parlor. Samples and data were collected during the last $4 \mathrm{~d}$ of each period.

\section{Data and Sample Collection}

Throughout the experiment, cows were fed once daily $(1100 \mathrm{~h})$ at $110 \%$ of expected intake. The amount of feed offered and orts were weighed for each cow daily during the collection period. Samples of all dietary ingredients $(0.5 \mathrm{~kg})$ and treatment diets were collected daily during the collection period and composited into one sample per period. Samples of orts $(12.5 \%)$ were collected daily during the collection period and composited into one sample per cow period. Blood was collected from a coccygeal vessel into a tube containing sodium heparin. Six samples were collected over $2 \mathrm{~d}$ (d 10 and 11) representing 4-h intervals of a 24 -h period to account for temporal variation. Blood was centrifuged at $2000 \times g$ for 15 min immediately after sample collection, and plasma was harvested and frozen at $-20^{\circ} \mathrm{C}$ until analysis. Cows were milked twice daily in the milking parlor throughout the experiment. Milk yield was measured and sampled at each milking from d 11 to 14 and averaged over the period. Feeding behavior was observed and recorded manually every $5 \mathrm{~min}$ for $24 \mathrm{~h}$ on d 14. Activity was classified as eating, ruminating, drinking, or idle. Cows were fed and milked as normal during feeding behavior observation. Body weight was recorded on the day before the start of the first period and on d 14 of each period to determine BW change. On the same days, 3 trained investigators determined BCS using a 5 -point scale ( $1=$ thin, 5 = fat; Wildman et al., 1982).

\section{Sample Analyses}

Milk samples were analyzed for fat, true protein, and lactose using a midinfrared spectrophotometer equipped with A and B filters (model B2000; Bentley Instruments, Chaska, MN). Diet ingredients and orts were dried in a $55^{\circ} \mathrm{C}$ forced-air oven for $72 \mathrm{~h}$. All samples were ground with a Wiley mill (1-mm screen; Arthur H. Thomas, Philadelphia, PA). Diet ingredients were analyzed for DM, NDF, ADF, starch, CP, ash, and FA concentration and profile. Neutral detergent fiber concentration was determined with the addition of heatstable amylase (Van Soest et al., 1991; method A). Starch was measured by an enzymatic method (Karkalas, 1985) after samples were gelatinized with sodium hydroxide. Crude protein was analyzed according to Hach et al. (1987). Ash content was determined after $6 \mathrm{~h}$ oxidation at $500^{\circ} \mathrm{C}$ in a muffle furnace. Fatty acids were extracted and methyl esters were prepared by acid-catalyzed transesterification (Sukhija and Palm- quist, 1988). Total FA concentration and FA profile was determined by GLC using an external standard. Concentrations of all nutrients except DM were expressed as percentages of $\mathrm{DM}$ determined from drying at $105^{\circ} \mathrm{C}$ in a forced-air oven.

Blood samples were analyzed for insulin, glucagon, somatotropin (ST), cholecystokinin (CCK), NEFA, glucose, and BHBA. Commercial radioimmunoassay kits were used to determine plasma concentration of insulin (Coat-A-Count; Diagnostic Products Corporation, Los Angeles, CA), glucagon (glucagon kit GL-32K; Linco Research, St. Charles, MO), and CCK (Euria-CCK kit RB302; ALPCO, Windham, NH). The glucagon procedure (Hammon and Blum, 1998) and CCK procedure (Benson and Reynolds, 2001) have previously been validated for use with bovine plasma. Plasma ST concentration was determined by radioimmunoassay (Gaynor et al., 1995). Enzymatic assays were used for determination of glucose (Raabo and Terkildsen, 1960; glucose kit \#510; Sigma Chemical Co., St. Louis, MO), NEFA (Johnson and Peters, 1993; NEFA C-kit; Wako Chemicals USA, Richmond, VA), and BHBA (Williamson et al., 1962; BHBA kit \#310-A; Sigma Chemical Co.) in a microplate reader (SpectraMax 190, Molecular Devices, Sunnyvale, CA).

Net energy of BW change was calculated according to NRC (2001) and net energy of milk production was calculated using the following equation (NRC, 2001):

$$
\begin{gathered}
\text { Milk } \mathrm{NE}_{\mathrm{L}}(\mathrm{Mcal} / \mathrm{d})=\text { Milk yield }(\mathrm{kg}) \\
\times[0.0929 \times(\text { Fat \% })+0.0563 \times(\text { True Protein \% }) \\
+0.0395 \times(\text { Lactose \% })]
\end{gathered}
$$

\section{Statistical Analyses}

For treatment effects, all data were analyzed by the fit model procedure of JMP Version 5.0 (SAS Institute, 2003) according to the following model:

$$
\mathrm{Y}_{\mathrm{ijkl}}=\mu+\mathrm{S}_{\mathrm{i}}+\mathrm{C}_{\mathrm{j}}\left(\mathrm{S}_{\mathrm{i}}\right)+\mathrm{P}_{\mathrm{k}}+\mathrm{T}_{1}+\mathrm{e}_{\mathrm{ijk} \mathrm{k}},
$$

where $\mu=$ overall mean, $S_{i}=$ fixed effect of sequence ( $\mathrm{i}=1$ to 2 ), $\mathrm{C}_{\mathrm{j}}\left(\mathrm{S}_{\mathrm{i}}\right)=$ random effect of cow nested in sequence $(j=1$ to 16$), P_{k}=$ fixed effect of period $(k=1$ to 2$), T_{1}=$ fixed effect of treatment $(\mathrm{l}=1$ to 2$)$, and $\mathrm{e}_{\mathrm{ijkl}}=$ residual error.

Pretrial fat-corrected milk yield (pFCMY) was calculated as the average daily production over 8 milkings during the $4 \mathrm{~d}$ immediately before the initiation of the experiment. Relationships between response to treatment and pFCMY were analyzed according to the following model: 


$$
\mathrm{Y}_{\mathrm{i}}=\mu+\mathrm{S}_{\mathrm{i}}+\mathrm{pM}+\mathrm{pM}^{2}+\mathrm{e}_{\mathrm{i}}
$$

where $\mathrm{Y}_{\mathrm{i}}=\mathrm{y}_{\mathrm{SAT}}-\mathrm{y}_{\mathrm{UNS}}, \mathrm{y}_{\mathrm{SAT}}=$ response for the saturated FA treatment, $\mathrm{y}_{\mathrm{UNS}}=$ response for the unsaturated FA treatment, $\mu=$ overall mean, $S_{i}=$ fixed effect of sequence ( $\mathrm{i}=1$ to 2 ), $\mathrm{pM}=\mathrm{pFCMY}, \mathrm{pM}^{2}=\mathrm{pFCMY}^{2}$, and $\mathrm{e}_{\mathrm{i}}=$ residual error.

Data points with Studentized Residuals greater than 3 were considered outliers and excluded from the data set. One cow was diagnosed with clinical mastitis in the first treatment period and was excluded from statistical analysis.

\section{RESULTS AND DISCUSSION}

Fat treatments differed in FA profile, with UNS containing nearly 2.5 times more unsaturated FA than SAT, primarily as C18:1 and C18:2 (Table 1). Treatments also differed in $\mathrm{C} 16: \mathrm{C} 18 \mathrm{FA}$ ratio because the UNS treatment contained high levels of palmitic acid. Diets contained nearly equal concentrations of starch, $\mathrm{CP}, \mathrm{NDF}$, and FA (Table 2).

\section{Intake and Chewing Behavior}

Unsaturated FA decreased DMI $0.8 \mathrm{~kg} / \mathrm{d}$ relative to SAT $(P<0.01)$ and decreased intake of starch, CP, and total FA $(P<0.01$; Table 3$)$. In previous direct comparisons of saturated and unsaturated FA supplements, no differences were observed in intake when supplemented at $0.68 \mathrm{~kg}$ of FA (Grummer, 1988; Schauff and Clark, 1989), and at 2 and $5 \%$ of the diet (Eastridge and Firkins, 1991). However, both of these studies had fewer observations, lower producing cows, and lower basal dietary FA concentration compared with the present experiment. The higher intakes in the current experiment may have increased ruminal passage rate resulting in decreased ruminal biohydrogenation and increased duodenal flow of unsaturated FA. Allen (2000) reported that in 11 out of 24 studies, calcium salts of palm FA caused a linear decrease in DMI, whereas 22 of the 24 experiments resulted in a numerical decrease in DMI. In contrast, hydrogenated triglyceride or FA resulted in decreased DMI in only one experiment and increased DMI in 2 out of 21 experiments reported.

Abomasal infusion of unsaturated fat consistently decreases DMI relative to no fat and saturated fat infusions (Benson and Reynolds, 2001). Drackley et al. (1992) and Christensen et al. (1994) both showed that abomasal infusions of $450 \mathrm{~g}$ of unsaturated FA with a lower C16:C18 FA ratio decreased DM intake compared with an equal amount of more saturated FA, whereas Drackley et al. (1992) also reported decreased digestible
Table 3. Effects of fatty acid (FA) saturation ${ }^{1}$ on intake and feeding behavior.

\begin{tabular}{lcccc}
\hline & SAT & UNS & SE & $P$ \\
\hline Intake, kg/d & & & & \\
DM & 27.4 & 26.7 & 0.4 & $<0.01$ \\
NDF & 6.93 & 6.88 & 0.09 & 0.39 \\
Starch & 6.79 & 6.62 & 0.10 & $<0.01$ \\
CP & 4.57 & 4.46 & 0.06 & $<0.01$ \\
Total FA & 1.85 & 1.75 & 0.02 & $<0.001$ \\
Unsaturated FA & 0.87 & 1.03 & 0.01 & $<0.001$ \\
$\quad$ Saturated FA & 0.75 & 0.52 & 0.006 & $<0.001$ \\
Feeding behavior & & & & \\
Eating time & 210 & 205 & 6 & 0.33 \\
$\quad$ min/d & 7.8 & 7.8 & 0.3 & 0.91 \\
min/kg of DMI & 31 & 30 & 1.0 & 0.40 \\
min/kg of NDF intake & & & & \\
Ruminating time & 535 & 510 & 10 & $<0.01$ \\
$\quad$ min/d & 77 & 74 & 1.8 & 0.03 \\
min/kg of NDF intake & & & & \\
Total chewing time & 745 & 715 & 13 & $<0.01$ \\
$\quad$ min/d & 108 & 104 & 2.3 & 0.02 \\
$\quad$ min/kg of NDF intake & 108 \\
Time spent idle & 670 & 695 & 10 & $<0.01$ \\
$\quad$ min/d &
\end{tabular}

${ }^{1} \mathrm{SAT}=$ Saturated fatty acid treatment of prilled fatty acids; UNS = unsaturated fatty acid treatment of calcium salts of palm fatty acids.

energy intake. Bremmer et al. (1998) demonstrated the negative relationship between intake and diet unsaturated FA concentration at the same $\mathrm{C} 16: \mathrm{C} 18 \mathrm{FA}$ ratio in abomasal infusions. In addition, oleamide FA consistently decreased intake compared with free oil that is readily biohydrogenated in the rumen (Jenkins, 2000). The experimental treatments in the current experiment differed in both unsaturated fat concentration and C16:C18 FA ratio; however, the experiments cited above provide strong evidence that FA-mediated intake depression is a function of FA saturation, independent of chain length.

Rumen biohydrogenation of unsaturated FA can be extensive and may explain differences in the magnitude and consistency of response when unsaturated fat is fed vs. directly infused into the abomasum. Ruminal biohydrogenation of unsaturated C18 FA fed as calcium salts of palm FA reported by Klusmeyer and Clark $(1990,1991)$ and Wu et al. (1991) was 34, 33, and 48\%, respectively. Fatty acids fed as calcium salts must first dissociate from the calcium ion and then be absorbed by rumen bacteria to undergo biohydrogenation (Jenkins, 1993). The rate of biohydrogenation is expected to be a function of the $\mathrm{pK}_{\mathrm{a}}$ for the calcium salt, rumen $\mathrm{pH}$, and the microbial population, which affects availability of FA and enzyme activity for biohydrogenation. The extent of biohydrogenation is a result of the rate of biohydrogenation and rumen retention time (Harvatine and Allen, 2004). Biohydrogenation of the UNS treatment in the current experiment is unknown. However, we expect that less unsaturated FA reached the duode- 
Table 4. Effects of fatty acid saturation ${ }^{1}$ on plasma hormones and metabolites.

\begin{tabular}{lcclc}
\hline & SAT & UNS & SE & $P$ \\
\hline Cholecystokinin, pmol/L & 12.5 & 14.1 & 0.91 & 0.08 \\
Insulin, $\mu$ IU/mL & 12.8 & 10.1 & 0.6 & $<0.001$ \\
Somatotropin, ng/mL & 1.94 & 1.98 & 0.14 & 0.76 \\
Glucose, mg/dL & 62.0 & 61.4 & 0.5 & 0.19 \\
NEFA, $\mu M$ & 89.3 & 115.5 & 3.3 & $<0.001$ \\
BHBA, mg/dL & 5.25 & 5.28 & 0.16 & 0.86 \\
\hline
\end{tabular}

${ }^{1} \mathrm{SAT}=$ Saturated fatty acid treatment of prilled fatty acids; UNS = unsaturated fatty acid treatment of calcium salts of palm fatty acids.

num than was fed, which demonstrates the powerful hypophagic effects of unsaturated FA or their products from biohydrogenation.

There was no effect of treatment on time spent eating but UNS decreased time spent ruminating $25 \mathrm{~min} / \mathrm{d}(P$ $<0.01)$ and increased time spent idle $25 \mathrm{~min} / \mathrm{d}(P<$ $0.01)$. Although its regulation is poorly understood, time spent chewing is primarily related to dietary intake and concentration of fiber and forage fiber, and is poorly related to DMI (Allen, 1997). Total chewing time and time spent ruminating per kilogram of NDF intake was decreased by UNS $(P<0.05$ and $P<0.01$, respectively; Table 3). Therefore, differences in chewing behavior observed in the current experiment cannot be attributed to differences in fiber intake. Treatment diets also contained the same base ration and are not expected to differ in effectiveness of stimulating rumination, although associative effects on ruminal fiber digestion and passage could have affected ruminal digesta pool size, leading to changes in rumination.

Deswysen et al. (1987) reported a strong positive relationship between the number of rumen contractions and rumination time, indicating that decreased time spent ruminating in the current experiment may be indicative of less reticular-rumen motility. Nicholson and Omer (1983) showed that intestinal infusion of unsaturated FA decreased rumen motility of sheep. Grovum (1986) reported almost total cessation of rumen motility after $13 \mathrm{~h}$ of intragastric infusion of unsaturated fat whereas intravenous infusion had little effect; decreased intake and frequency of biphasic and triphasic rumen contractions were observed within $3 \mathrm{~h}$ of intragastric infusion of unsaturated FA. Differences in gastric and venous infusions implicate involvement of the gut in FA depression of reticular-rumen motility. Dry matter intake was decreased and postprandial CCK was increased when diets were supplemented with calcium salts of palm FA (Choi and Palmquist, 1996), and direct intravenous infusions of CCK depressed reticular-rumen motility and intake in sheep (Grovum, 1981). In the current experiment, we observed a tendency for increased plasma CCK with UNS FA (Table 4). Increased plasma concentrations of glucagon-like peptide-1 (GLP-1) have been observed with unsaturated fat infusion by Benson and Reynolds (2001) and Litherland et al. (2005). Glucagon-like peptide- 1 is a gut peptide with similar secretion to CCK. These observations are consistent with gut peptide secretion in response to FA ingestion with subsequent effects on intake and gut motility (Reidelberger, 1994).

Experiments testing the effect of FA on rumen motility and gut peptide secretion have used no fat controls and the effect of FA saturation on endocrine signaling and rumen motility has not been explored. Differences in rumination with varying $\mathrm{FA}$ saturation in the current experiment are consistent with FA saturation changing gut peptide secretion. Fatty acids may directly affect gut peptide secretion or change temporal release of gut peptides relative to a meal, thereby changing gut motility. Absorption of FA and stimulation of gut peptide secretion likely coincide with rumination bouts between meals as the rumen creates a lag between intake of FA and their flow to the duodenum. Changing reticulorumen motility may then modify time spent ruminating. Differences in rumination and reticular motility may also change rumen distension from physical fill because of slower digestion and passage of digesta.

Dry matter intake response (SAT - UNS) was not related to $\mathrm{pFCMY}$ or pretrial fat yield (Table 5). In addition, there was no relationship between pretrial parameters and chewing behavior responses. Failure to detect a relationship of DMI response with $\mathrm{pFCMY}$ discounts physical fill and absorbed energy as mechanisms of unsaturated FA-induced hypophagia. Intake of high-producing cows in less positive energy balance is expected to be limited primarily by physical fill, whereas intake of lower producing cows in more positive energy balance is expected to be limited primarily by absorbed fuels. Observed intake responses in the current experiment cannot be attributed entirely to either mechanism. Digestibility of saturated FA is commonly thought to be lower than unsaturated fat (Palmquist, 1984). However, FA digestibility cannot be determined by measuring digestibility of individual FA fed in a mixture because hindgut biohydrogenation inflates recovery of saturated FA at the expense of unsaturated fat, causing overestimation of unsaturated FA and underestimation of saturated free FA digestibility. Other experiments have concluded that the intake depression of unsaturated FA is not mediated by differences in digestibility when supplemented in free FA form. The abomasal infusions previously discussed (Drackley et al., 1992; Christensen et al., 1994; Bremmer et al., 1998) did not show differences in FA or energy digestibility when directly comparing saturated and unsaturated FA treatments. Finally, Schauff and Clark (1989), 
Table 5. Responses (saturated - unsaturated) of intake and production by pretrial 3.5\% fat-corrected milk yield.

\begin{tabular}{|c|c|c|c|c|c|}
\hline Response & $\mathrm{R}^{2}$ & Predictor $^{1}$ & $P^{2}$ & Coefficient $^{3}$ & Intercept $^{4}$ \\
\hline DMI & 0.19 & $\mathrm{pFCMY}^{5}$ & 0.14 & - & - \\
\hline Milk yield, kg/d & 0.39 & pFCMY & 0.24 & - & - \\
\hline $3.5 \% \mathrm{FCM}, \mathrm{kg} / \mathrm{d}$ & 0.19 & pFCMY & 0.48 & - & - \\
\hline Fat, \% & 0.06 & pFCMY & 0.84 & - & - \\
\hline Fat yield, kg & 0.02 & pFCMY & 0.75 & - & - \\
\hline Protein, $\%$ & 0.46 & $\begin{array}{l}\text { Sequence } \\
\text { pFCMY }\end{array}$ & $\begin{array}{l}<0.001 \\
<0.05\end{array}$ & $\begin{array}{l}0.174 \\
0.049\end{array}$ & -0.204 \\
\hline Protein yield, kg & 0.18 & $\begin{array}{l}\text { Sequence } \\
\text { pFCMY }\end{array}$ & $\begin{array}{l}0.48 \\
0.02\end{array}$ & $\begin{array}{r}-0.008 \\
0.004\end{array}$ & -0.173 \\
\hline Lactose, \% & 0.34 & $\begin{array}{l}\text { Sequence } \\
\text { pFCMY } \\
(\mathrm{pFCMY})^{2}\end{array}$ & $\begin{array}{r}<0.01 \\
0.01 \\
<0.01\end{array}$ & $\begin{array}{l}0.006 \\
0.011 \\
0.009\end{array}$ & 1.05 \\
\hline Lactose yield, kg & 0.66 & $\begin{array}{l}\text { Sequence } \\
\text { pFCMY } \\
(\text { pFCMY) }\end{array}$ & $\begin{array}{l}<0.001 \\
<0.01 \\
<0.01\end{array}$ & $\begin{array}{c}-0.095 \\
-0.049 \\
0.0006\end{array}$ & 0.965 \\
\hline
\end{tabular}

\footnotetext{
${ }^{1}$ Regression term.

${ }^{2} P=$ Probability for effect of regression term.

${ }^{3}$ Coefficient of the regression term.

${ }^{4}$ Intercept of the regression equation.

${ }^{5} \mathrm{pFCMY}=$ Pretrial $3.5 \%$ fat-corrected milk yield $(\mathrm{kg} / \mathrm{d})$.

${ }^{6}$ Sequence parameter estimate.
}

Grummer (1988), and Palmquist (1991) directly compared calcium salts of palm FA and saturated free FA (same treatments as this experiment) and found no difference in apparent total tract digestibility of energy, lipid, and FA, respectively.

\section{Production}

There were no treatment effects of FA type on yield of milk or milk components (Table 6). Production responses to supplemental fat are inconsistent across experiments. Chilliard (1993) reviewed the effect of fat

Table 6. Effects of fatty acid saturation on production. ${ }^{1}$

\begin{tabular}{lcccc}
\hline & SAT & UNS & SE & $P$ \\
\hline Yield, kg/d & & & & \\
Milk & 41.8 & 42.3 & 1.1 & 0.12 \\
$3.5 \%$ FCM & 41.8 & 42.4 & 1.2 & 0.11 \\
SCM & 39.0 & 39.3 & 1.1 & 0.33 \\
Fat & 1.47 & 1.49 & 0.05 & 0.25 \\
Protein & 1.27 & 1.27 & 0.03 & 0.79 \\
Lactose & 2.00 & 2.01 & 0.06 & 0.23 \\
Milk composition, \% & & & & \\
Fat & 3.54 & 3.54 & 0.09 & 0.92 \\
Protein & 3.06 & 3.02 & 0.05 & 0.04 \\
$\quad$ Lactose & 4.80 & 4.74 & 0.03 & $<0.001$ \\
Tissue gain & & & & \\
$\quad$ BW change, kg/d & 0.50 & 0.29 & 0.16 & 0.37 \\
BCS change & & & & \\
BCS & 0.11 & 0.10 & 0.04 & 0.74 \\
\hline
\end{tabular}

${ }^{1} \mathrm{SAT}=$ Saturated fatty acid treatment of prilled fatty acids; UNS = unsaturated fatty acid treatment of calcium salts of palm fatty acids.

${ }^{2}$ Change in BCS (5-point scale where 1 = thin to 5 = fat) over a 14 d period. supplementation and noted little difference in FCM in short-term experiments, presumably because of a 2-to3 -wk production lag observed in long-term fat studies. Experimental periods of $14 \mathrm{~d}$, as used in the current experiment, may be too short to establish effects on milk yield.

Unsaturated FA treatment decreased milk protein and lactose concentration relative to SAT (protein 3.06 and $3.02 \%$, and lactose 4.80 and $4.74 \%$ for SAT and UNS, respectively). Responses (SAT - UNS) of milk protein yield and concentration were positively related to milk yield (Figure 1, $P=0.02, \mathrm{R}^{2}=0.18$; and Figure $2, P<0.05, \mathrm{R}^{2}=0.46$, respectively). The percentage change in milk protein yield was also tested and was significant but is not reported. High-producing cows had larger milk protein yield responses when fed SAT compared with UNS than did cows with lower milk yield. Responses in individual cow FCM, milk fat yield, and fat percentage were not related to pretrial production. The production level or metabolic state by response interaction that we observed for milk protein may explain the inconsistent reports of FA effects on milk protein synthesis. Nonresponding cows in some experiments, but not in others, may simply dilute treatment effects or add unexplainable variation.

Decreased milk protein concentration is commonly attributed to the diluting effect of increased milk yield. In the current experiment, there was no relationship between the response for milk protein percentage (SAT - UNS) and the response for milk yield (SAT - UNS, $\left.\mathrm{R}^{2}=0.41, P=0.23\right)$. There was no dilution effect of milk 


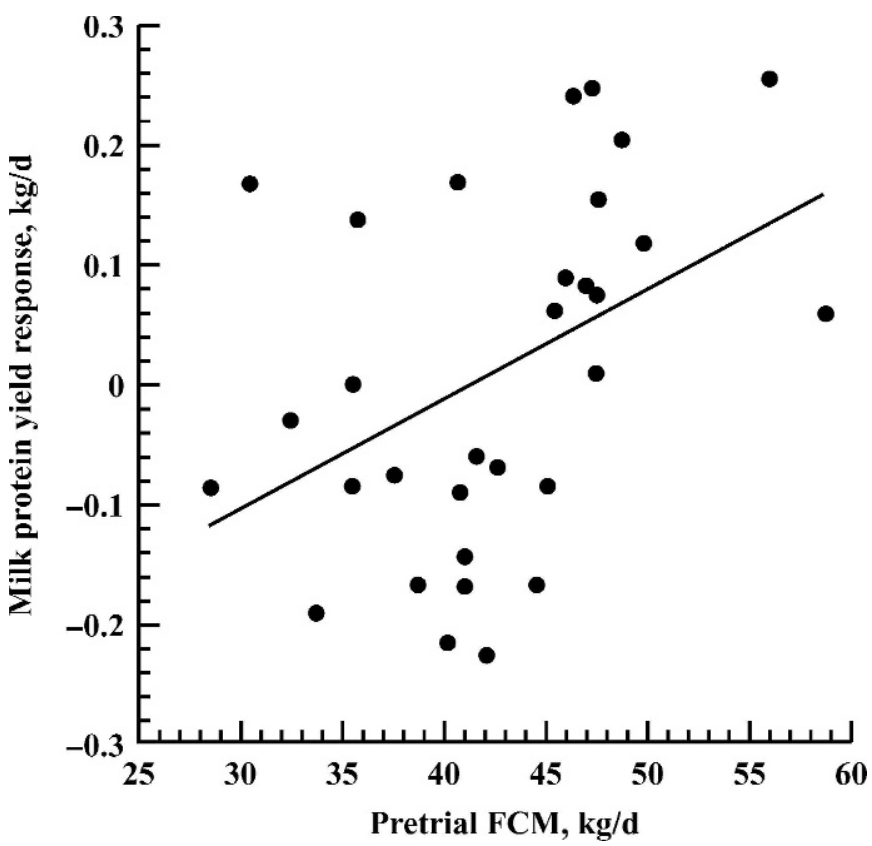

Figure 1. Relationship between milk yield over the $4 \mathrm{~d}$ before the beginning of the trial (pretrial FCM) and the response (saturated unsaturated) in milk protein concentration to the unsaturated fatty acid treatment $\left(\mathrm{y}=-0.38+0.0092 \mathrm{x} ; P=0.02, \mathrm{R}^{2}=0.18\right)$.

protein observed because milk protein yield response linearly increased with increased milk yield response $\left(\mathrm{R}^{2}=0.55, P<0.001\right)$. Although not observed in the current experiment, dilution of milk protein by increased milk production merits further investigation. Protein and lactose concentration of milk are both very stable and expected to be highly correlated; $\mathrm{Wu}$ and Huber (1994) reported a linear relationship between milk and milk protein yield with an $\mathrm{R}^{2}$ of 0.90 . Dilution of milk protein by increased milk yield would represent a deviation from normal and should not be ignored.

Emery (1978) reported that milk protein concentration decreased 0.1 to 0.3 percentage points with added fat, and DePeters and Cant (1992) reviewed the effect of fat on milk protein showing variation in published responses. Chilliard (1993) reviewed the effects of fat on production and noted that milk protein concentration decreased in response to fat supplementation to a greater extent in early lactation compared with peak lactation $(0.8$ vs. $0.5 \mathrm{~g} / \mathrm{kg})$ and in short-term experiments compared with long-term experiments (1.0 vs. $0.5 \mathrm{~g} / \mathrm{kg}$ ). In direct comparisons of dietary saturated and unsaturated FA supplements, Grummer (1988) showed unsaturated FA decreased milk protein $0.13 \%$ compared with no fat control, and saturated fat treatment maintained milk protein. Schauff and Clark (1989) observed no effect of fat type on milk protein. Dietary FA

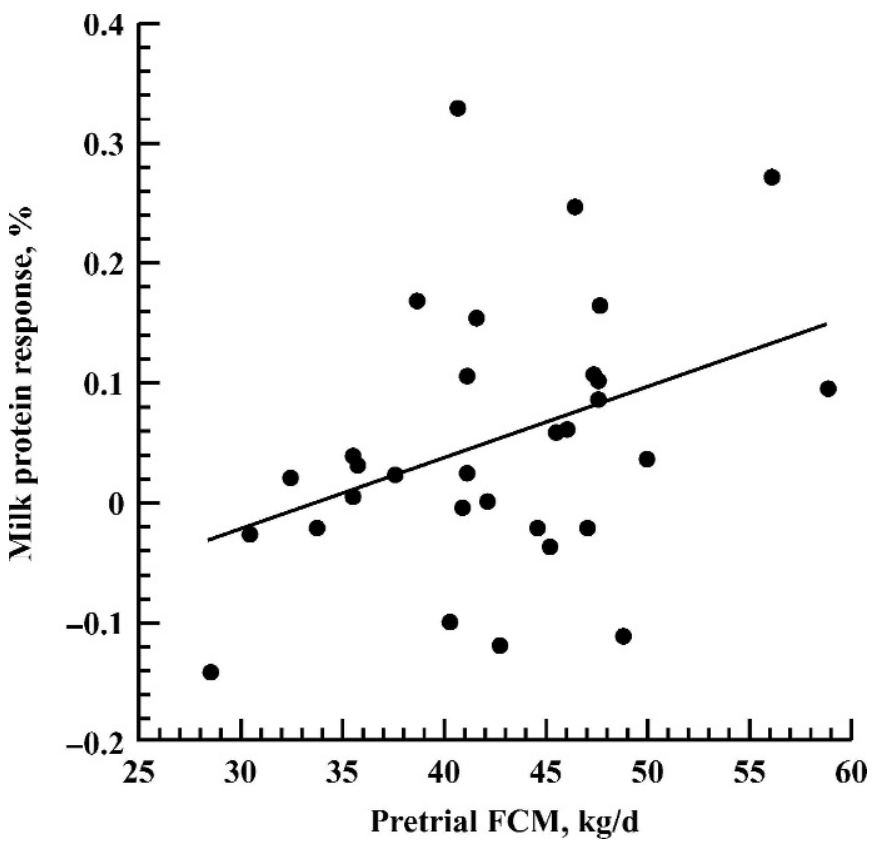

Figure 2. Relationship between milk yield over the $4 \mathrm{~d}$ before the beginning of the trial (pretrial FCM) and the response (saturated - unsaturated) in milk protein yield to the unsaturated fatty acid treatment $\left(\mathrm{y}=-0.204+0.006 \mathrm{x} ; P=0.048, \mathrm{R}^{2}=0.46\right)$.

saturation appears to be an important factor affecting milk protein response to FA treatment. Possible mechanisms include inhibition of microbial protein production, modification of insulin signaling, and changes in the somatotropic axis.

Unsaturated FA fed as calcium salts of palm FA are partially available for biohydrogenation, and may interfere with microbial growth rate or efficiency. Fatty acids may decrease milk protein because of decreased microbial protein yields making less protein absorbed and available for milk protein synthesis. However, feeding protected oleic acid in the form of oleamide decreased milk protein concentration and yield (Jenkins, 2000) compared with raw canola oil (high oleic acid). Free oil interferes with ruminal fermentation more than oleamide but had less of an effect on milk protein synthesis than the physiological effects of absorbed unsaturated FA.

Hyperinsulinemic-euglycemic clamp studies have identified insulin, or its stimulation of IGF, as a regulator of milk protein synthesis (Mackle et al., 2000). Increased milk protein synthesis in the clamp procedure is not solely the effect of infused glucose sparing amino acids because cows supported increased protein synthesis by increasing the extraction efficiency of essential amino acids, mammary blood flow, and glucose uptake (Mackle et al., 2000). In the present experiment, SAT 
Table 7. Responses (saturated - unsaturated) of energy balance and plasma metabolites and hormones.

\begin{tabular}{lllrrr}
\hline Response & $\mathrm{R}^{2}$ & Predictor & \multicolumn{1}{c}{$P^{2}$} & Coefficient $^{3}$ & Intercept $^{4}$ \\
\hline NEFA & \multirow{2}{*}{0.28} & Sequence & 0.46 & -1.90 & -190.5 \\
& & pFCMY & 0.02 & 8.27 & \\
Somatotropin/insulin & \multirow{2}{*}{0.36} & (pFCMY) $\times(\mathrm{pFCMY})$ & 0.01 & -0.10 & -1.287 \\
& & Sequence & $<0.01$ & 0.073 & 0.063 \\
& & pFCMY & 0.03 & -0.00078 & \\
\hline
\end{tabular}

\footnotetext{
${ }^{1}$ Predictor $=$ Regression term.

${ }^{2} P=$ Probability for effect of regression term.

${ }^{3}$ Coefficient of the regression term.

${ }^{4}$ Intercept of the regression equation.

${ }^{5} \mathrm{pFCMY}=$ Pretrial $3.5 \%$ fat-corrected milk yield $(\mathrm{kg} / \mathrm{d})$.
}

increased insulin $25 \%$ as well as milk protein concentration and yield consistent with the insulin clamp model. Surprisingly, although milk protein response was related to $\mathrm{pFCMY}$, insulin response (SAT - UNS) was not. There was no relationship between milk protein response and insulin response after accounting for sequence $(P=0.89)$. If insulin is involved in regulation of milk protein synthesis, it is reasonable to expect that not just the plasma insulin concentration, but also tissue sensitivity to insulin stimulation is important. Palmquist and Moser (1981) studied the relationship of dietary unsaturated fat, plasma glucose, and insulin, and milk protein production. Glucose tolerance tests were used to measure insulin responsiveness and sensitivity. Cows fed calcium salts of palm FA responded to glucose infusion with more insulin secretion and had slower clearance of glucose, suggesting increased insulin resistance. The authors proposed that fat-stimulated insulin resistance might reduce amino acid transport into the mammary gland. The lack of a relationship between plasma insulin concentration and milk protein response and insulin response and pretrial production level in the current experiment supports the hypothesis that tissue insulin sensitivity is important to milk protein production.

Insulin stimulation of the somatotropic axis cannot be ruled out as a possible mechanism for increasing milk protein synthesis. Molento et al. (2002) showed that insulin stimulated IGF-I production in early to midlactation cows. They proposed that the ST to insulin ratio was an important predictor of IGF-I production, with lower ratios correlating to higher IGF-I concentrations. In the present experiment, increased insulin with no change in plasma ST would be expected to increase plasma IGF-I concentration. In addition, there was a significant quadratic relationship between the ST/insulin response and milk protein response (Table 7).

\section{Energy Balance and Efficiency}

Treatments did not affect BW gain or BCS changes. There was also no relationship between measures of energy balance and pretrial milk yield. Experimental periods were only $14 \mathrm{~d}$ in length, reducing our ability to detect body tissue changes. The lack of effects of treatment on BW, BCS, or plasma ST concentration indicates that cows did not change energy balance or that experimental periods were too short to observe differences.

Treatment diets contained nearly equal nutrient compositions and were considered to contain the same gross energy density. Efficiency calculated as FCM yield per kilogram of DMI was greater for UNS than SAT cows $(P<0.001$; Table 8$)$. This calculation does not account for changes in body energy, and treatment effects were not significant for either milk yield or BW change. Efficiency calculated as net energy $\left(\mathrm{NE}_{\mathrm{L}}\right)$ of $\mathrm{BW}$ change plus $\mathrm{NE}_{\mathrm{L}}$ milk production over DMI was not different between treatments. Body weight energy gain and milk energy yield were not different between treatments, attributing any efficiency difference to changes in DM intake.

The return provided by the incremental increase in DM intake, or marginal return (Penson et al., 2002), is a more informative variable than absolute efficiency because it highlights diminishing returns of inputs expected in biological systems. Milk yield and milk protein

Table 8. Effects of fatty acid saturation ${ }^{1}$ on energy intake and partitioning.

\begin{tabular}{|c|c|c|c|c|}
\hline & SAT & UNS & $\mathrm{SE}$ & $P$ \\
\hline Milk energy, Mcal $\mathrm{NE}_{\mathrm{L}}^{2}$ & 28.7 & 29.9 & 0.77 & 0.33 \\
\hline Tissue energy gain, ${ }^{3}$ Mcal $\mathrm{NE}_{\mathrm{L}}$ & 2.90 & 2.36 & 1.11 & 0.73 \\
\hline Efficiency, FCM/DMI & 1.53 & 1.59 & 0.04 & $<0.001$ \\
\hline Energy efficiency ${ }^{4}$ & 0.54 & 0.55 & 0.02 & 0.76 \\
\hline
\end{tabular}

${ }^{1} \mathrm{SAT}=$ Saturated fatty acid treatment of prilled fatty acids, UNS = unsaturated fatty acid treatment of calcium salts of palm fatty acids.

${ }^{2} \mathrm{NE}_{\mathrm{L}(\text { milk })}(\mathrm{Mcal} / \mathrm{d})=\mathrm{MY}(\mathrm{kg}) \times(0.0929 \times$ fat $\%+0.0563 \times$ true protein $\%+0.0395 \times$ lactose $\%) ; \mathrm{NRC}, 2001$.

${ }^{3} \mathrm{NE}_{\mathrm{L}}$ gain calculated from $\mathrm{BW}$ gain (NRC, 2001).

${ }^{4}$ Energy efficiency $=\left(\right.$ milk energy, $\mathrm{Mcal} \mathrm{NE_{ \textrm {L } }}+$ tissue energy gain, Mcal $\left.\mathrm{NE}_{\mathrm{L}}\right) / \mathrm{kg}$ of DM. 
Table 9. Milk yield and component responses (saturated - unsaturated) by DM intake response (saturated - unsaturated)

\begin{tabular}{|c|c|c|c|c|c|}
\hline Response & $\mathrm{R}^{2}$ & Predictor $^{1}$ & $P^{2}$ & Coefficient $^{3}$ & Intercept $^{4}$ \\
\hline Milk yield, kg/d & 0.53 & $\begin{array}{l}\text { Sequence } \\
\text { DMI Response }\end{array}$ & $\begin{array}{l}<0.01 \\
<0.01\end{array}$ & $\begin{array}{r}-0.98 \\
0.82\end{array}$ & -1.10 \\
\hline $3.5 \% \mathrm{FCM}, \mathrm{kg} / \mathrm{d}$ & 0.43 & $\begin{array}{l}\text { Sequence } \\
\text { DMI Response } \\
\text { (DMI Response }) \times(\text { DMI Response })\end{array}$ & $\begin{array}{l}0.09 \\
0.67 \\
0.01\end{array}$ & $\begin{array}{r}-0.69 \\
0.17 \\
0.36\end{array}$ & -1.26 \\
\hline Milk fat, $\%$ & 0.32 & $\begin{array}{l}\text { Sequence } \\
\text { DMI Response } \\
\text { (DMI Response }) \times(\text { DMI Response })\end{array}$ & $\begin{array}{r}0.17 \\
0.03 \\
<0.01\end{array}$ & $\begin{array}{r}0.06 \\
-0.05 \\
0.01\end{array}$ & 0.015 \\
\hline Milk fat yield, $\mathrm{kg}$ & 0.35 & $\begin{array}{l}\text { Sequence } \\
\text { DMI Response } \\
\text { (DMI Response }) \times(\text { DMI Response })\end{array}$ & $\begin{array}{r}0.63 \\
0.67 \\
<0.01\end{array}$ & $\begin{array}{r}-0.01 \\
-0.01 \\
0.02\end{array}$ & -0.040 \\
\hline Milk protein, \% & 0.41 & $\begin{array}{l}\text { Sequence } \\
\text { DMI Response }\end{array}$ & $\begin{array}{c}<0.001 \\
0.24\end{array}$ & $\begin{array}{l}0.09 \\
0.01\end{array}$ & 0.034 \\
\hline Protein yield, kg & 0.39 & $\begin{array}{l}\text { Sequence } \\
\text { DMI Response }\end{array}$ & $\begin{array}{c}0.23 \\
<0.001\end{array}$ & $\begin{array}{l}0.01 \\
0.04\end{array}$ & -0.023 \\
\hline
\end{tabular}

${ }^{1}$ Predictor $=$ regression term.

${ }^{2} P=$ Probability for effect of regression term.

${ }^{3}$ Coefficient of the regression term.

${ }^{4}$ Intercept of the regression equation.

${ }^{5}$ DMI Response $=($ saturated DMI - unsaturated DMI $)$.

yield responses (SAT - UNS) were linearly increased with increased DMI response $(P<0.01$ and $P<0.001$, respectively). Fat-corrected milk, milk fat percentage, and milk fat yield responses (SAT - UNS) were affected quadratically by increasing DMI response $(P<0.01)$. Marginal milk and milk protein yield were linearly increased and marginal milk fat yield was affected quadratically with increasing DMI response (Table 9). Increasing DMI increased production of milk and milk components. The cost of the additional production is merely the increased DMI when using marginal return and describes the incremental returns of additional independent interventions.

\section{Plasma Metabolites and Hormones}

Saturated FA increased insulin over $25 \%$ compared with UNS (12.8 vs. $10.1 \mu \mathrm{IU} / \mathrm{mL}, P<0.001)$. Type of FA determines insulin secretion in vitro with saturated and longer chain FA being more insulinotropic (Stein et al., 1997). Plasma growth hormone concentrations were not affected by treatment. Saturated FA treatment decreased NEFA over 20\% compared with UNS (89.3 vs. $115.5 \mu \mathrm{Eq} / \mathrm{L}$ respectively, $P<0.001$ ), but plasma glucose and BHBA were not affected by treatment. A quadratic effect of pFCMY was observed on plasma NEFA. Interestingly, all cows decreased plasma NEFA when fed SAT compared with UNS. No other plasma hormone or metabolite was related to pFCMY.

\section{CONCLUSIONS}

Fatty acid profile reaching the duodenum is important for predicting DMI response to fat supplemen- tation. Increasing unsaturated FA concentration of the diet decreased DMI with no relationship to milk yield across cows. Saturated FA increased time spent ruminating compared with unsaturated FA, which may be the result of changes in gut motility as previously observed in abomasal infusions. Dietary FA saturation affects plasma insulin and NEFA concentration. Saturated FA increased milk protein, and the magnitude of the response appears to be related to production level and possibly insulin signaling. The current experiment observed animal responses to short-term feeding of fat supplements; responses to long term feeding should be verified in future experiments.

\section{ACKNOWLEDGMENTS}

We wish to acknowledge Milk Specialties Company (Dundee, IL) for partial financial support of this research. We also thank D. G. Main, R. A. Longuski, Y. Ying, M. Oba, C. S. Mooney, J. V. Voelker, C. C. Taylor, B. J. Bradford, R. E. Kreft, and the staff of the Michigan State University Dairy Cattle Teaching and Research Center for their assistance in this experiment, and D. Palmquist and T. Wolbaugh for fatty acid analysis.

\section{REFERENCES}

Allen, M. S. 1997. Relationship between fermentation acid production in the rumen and the requirement for physically effective fiber. J. Dairy Sci. 80:1447-1462.

Allen, M. S. 2000. Effects of diet on short-term regulation of feed intake by lactating dairy cattle. J. Dairy Sci. 83:1598-1624.

Benson, J. A., and C. K. Reynolds. 2001. Effects of abomasal infusion of long-chain fatty acids on splanchnic metabolism of pancreatic and gut hormones in lactating dairy cows. J. Dairy Sci. $84: 1488-1500$. 
Bremmer, D. R., L. D. Ruppert, J. H. Clark, and J. K. Drackley. 1998. Effects of chain length and unsaturation of fatty acid mixtures infused into the abomasum of lactating dairy cows. J. Dairy Sci. 81:176-188.

Chilliard, Y. 1993. Dietary fat and adipose tissue metabolism in ruminants, pigs, and rodents: A review. J. Dairy Sci. 76:3897-3931.

Choi, B. R., and D. L. Palmquist. 1996. High fat diets increase plasma cholecystokinin and pancreatic polypeptide, and decrease plasma insulin and feed intake in lactating cows. J. Nutr. 126:2913-2919.

Christensen, R. A., J. K. Drackley, D. W. LaCount, and J. H. Clark. 1994. Infusion of four long-chain fatty acid mixtures into the abomasum of lactating dairy cows. J. Dairy Sci. 77:1052-1069.

DePeters, E. J., and J. P. Cant. 1992. Nutritional factors influencing the nitrogen composition of bovine milk: A review. J. Dairy Sci. 75:2043-2070.

Deswysen, A. G., W. C. Ellis, and K. R. Pond. 1987. Interrelationships among voluntary intake, eating and ruminating behavior and ruminal motility of heifers fed corn silage. J. Anim. Sci. 64:835-841.

Drackley, J. K., T. H. Klusmeyer, A. M. Trusk, and J. H. Clark. 1992. Infusion of long-chain fatty acids varying in saturation and chain length into the abomasum of lactating dairy cows. J. Dairy Sci. $75: 1517-1526$

Eastridge, M. L., and J. L. Firkins. 1991. Feeding hydrogenated fatty acids and triglycerides to lactating dairy cows. J. Dairy Sci. 74:2610-2616

Emery, R. S. 1978. Feeding for increased milk protein. J. Dairy Sci. 61:825-828.

Gaynor, P. J., K. J. Lookingland, and H. A. Tucker. 1995. 5-Hydroxytryptaminergic receptor-stimulated growth hormone secretion occurs independently of changes in peripheral somatostatin concentration. Proc. Soc. Exp. Biol. Med. 209:79-85.

Grovum, W. L. 1981. Factors affecting the voluntary intake of food by sheep. 3 . The effect of intravenous infusions of gastrin, cholecystokinin and secretin on motility of the reticulo-rumen and intake. Br. J. Nutr. 45:183-201.

Grovum, W. L. 1986. The control of motility of the ruminoreticulum. Pages 18-40 in Control of Digestion and Metabolism in Ruminants. L. P. Milligan, W. L. Grovum, and A. Dobson, ed. PrenticeHall, Englewood Cliffs, NJ.

Grummer, R. R. 1988. Influence of prilled fat and calcium salt of palm oil fatty acids on ruminal fermentation and nutrient digestibility. J. Dairy Sci. 71:117-123.

Hach, C. C., B. K. Bowden, A. B. Lopelove, and S. V. Brayton. 1987. More powerful peroxide Kjeldahl digestion method. J. AOAC 70:783-787.

Hammon, H. M., and J. W. Blum. 1998. Metabolic and endocrine traits of neonatal calves are influenced by feeding colostrums for different durations or only milk replacer. J. Nutr. 128:624-632.

Harvatine, K. J., and M. S. Allen. 2004. Kinetic model of rumen biohydrogenation: Effects of rumen-protected fatty acid saturation on fractional rate of biohydrogenation and duodenal fatty acid flow in lactating dairy cows. J. Dairy Sci. 87(Suppl. 1):308. (Abstr.)

Jenkins, T. C. 1993. Lipid metabolism in the rumen. J. Dairy Sci. $76: 3851-3863$

Jenkins, T. C. 2000. Feeding oleamide to lactating Jersey cows 1. Effects on lactation performance and milk fatty acid composition. J. Dairy Sci. 83:332-337.

Johnson, M. J., and J. P. Peters. 1993. Technical note: An improved method to quantify nonesterified fatty acids in bovine plasma. J. Anim. Sci. 71:753-756.

Karkalas, J. 1985. An improved enzymatic method for the determination of native and modified starch. J. Sci. Food Agric. 36:10191027.

Klusmeyer, T. H., and J. H. Clark. 1991. Effects of dietary fat and protein on fatty acid flow to the duodenum and in milk produced by dairy cows. J. Dairy Sci. 74:3055-3067.
Klusmeyer, T. H., G. L. Lynch, J. H. Clark, and D. R. Nelson. 1991. Effects of calcium salts of fatty acids and proportion of forage in diet on ruminal fermentation and nutrient flow to duodenum of cows. J. Dairy Sci. 74:2220-2232.

Litherland, N. B., S. Thire, A. D. Beaulieu, C. K. Reynolds, J. A Benson, and J. K. Drackley. 2005. Dry matter intake is decreased more by abomasal infusion of unsaturated free fatty acids than by unsaturated triglycerides. J. Dairy Sci. 88:632-643.

Mackle, T. R., D. A. Dwyer, K. L. Ingvartsen, P. Y. Chouinard, D. A Ross, and D. E. Bauman. 2000. Effects of insulin and postruminal supply of protein on use of amino acids by the mammary gland for milk protein synthesis. J. Dairy Sci. 83:93-105.

Molento, C. F., E. Block, R. I. Cue, and D. Petitclerc. 2002. Effects of insulin, recombinant bovine somatotropin, and their interaction on insulin-like growth factor-I secretion and milk protein production in dairy cows. J. Dairy Sci. 85:738-747.

Nicholson, T., and S. A. Omer. 1983. The inhibitory effect of intestinal infusions of unsaturated long-chain fatty acids on forestomach motility of sheep. Br. J. Nutr. 50:141-149.

NRC. 2001. Nutrient Requirements of Dairy Cattle. 7th rev. ed. Natl. Acad. Sci., Washington, DC.

Palmquist, D. L. 1984. Use of fats in diets for lactating dairy cows. Pages 357-381 in Fats in Animal Nutrition. J. Wiseman, ed. Buttersworths, London, UK.

Palmquist, D. L. 1991. Influence of source and amount of dietary fat on digestibility in lactating cows. J. Dairy Sci. 74:1354-1360.

Palmquist, D. L., and E. A. Moser. 1981. Dietary fat effects on blood insulin, glucose utilization, and milk protein content of lactating cows. J. Dairy Sci. 64:1664-1670.

Penson, J. B., II, O. Capps, II, and C. P. Rosson, III. 2002. Pages 144-149 in Introduction to Agricultural Economics. 3rd ed. Prentice Hall, Upper Saddle River, NJ.

Raabo, E., and T. C. Terkildsen. 1960. On the enzymatic determination of blood glucose. Scand. J. Clin. Lab. Invest. 12:402-407.

Reidelberger, R. D. 1994. Cholecystokinin and control of food intake. J. Nutr. 124:1327S-1333S.

SAS Institute. 2003. JMP User's Guide: Statistical Discovery Software. Version 4 ed. SAS Inst., Inc., Cary, NC.

Schauff, D. J., and J. H. Clark. 1989. Effects of prilled fatty acids and calcium salts of fatty acids on rumen fermentation, nutrient digestibilities, milk production, and milk composition. J. Dairy Sci. 72:917-927.

Stein, D. T., B. E. Stevenson, M. W. Chester, M. Basit, M. B. Daniels, S. D. Turley, and J. D. McGarry. 1997. The insulinotropic potency of fatty acids is influenced profoundly by their chain length and degree of saturation. J. Clin. Invest. 100:398-403.

Sukhija, P. S., and D. L. Palmquist. 1988. Rapid method for determination of total fatty acid content and composition of feedstuffs and feces. J. Agric. Food Chem. 36:1202-1206.

Van Soest, P. J., J. B. Robertson, and B. A. Lewis. 1991. Methods for dietary fiber, neutral detergent fiber, and nonstarch polysaccharides in relation to animal nutrition. J. Dairy Sci. 74:35833597.

Wildman, E., G. Jones, P. Wagner, R. Boman, H. F. Troutt, Jr., and T. Lesch. 1982. A dairy cow body condition scoring system and its relationship to selected production characteristics. J. Dairy Sci. 65:495-501.

Williamson, D. H., J. Mellanby, and H. A. Krebs. 1962. Enzymatic determination of $\mathrm{D}(-) \beta$-hydroxybutyric acid and acetoacetic acid in blood. Biochem. J. 82:90-99.

Wu, Z., and J. T. Huber. 1994. Relationship between dietary fat supplementation and milk protein concentration in lactating cows: A review. Livest. Prod. Sci. 39:141-155.

Wu, Z., O. A. Ohajuruka, and D. L. Palmquist. 1991. Ruminal synthesis, biohydrogenation, and digestibility of fatty acids by dairy cows. J. Dairy Sci. 74:3025-3034. 